\title{
Three new species of Collembola from India
}

\author{
G. P. Mandal* \\ Zoological Survey of India, M-Block, New Alipore, Kolkata - 700053, \\ West Bengal, India; gpmandal.zsi@gmail.com
}

\section{Abstract}

Three new species of Collembola belonging to genera: Calx, Folsomia and Bourletiella under three families have been described from the states of Jharkhand, Arunachal Pradesh and Meghalaya, India. An identification key to the Indian species and their distribution are also provided.

Keywords: Bourletiellidae, Collembola, Entomobryidae, India, Isotomidae, New Species

\section{Introduction}

The present study of collembolan fauna is based on collection made from three different states of India, Jharkhand, Arunachal Pradesh and Meghalaya, as a part of the "Annual Action Plan" of Zoological Survey of India.

The species belonging to the family Entomobryidae, Isotomidae and Bourletiellidae, identified of the collembolan found are included into the genera, Calx, Folsomia and Bourletiella. A total of 3 species of Collembola belonging to 3 genera under 3 families Entomobryidae, Isotomidae and Bourletiellidae have been described as new to science from India. The detailed descriptions of each species of Collembola with discussion for difference between closely related species, total numbers of species in the world as well as from India, key to the Indian species and their distribution are also provided.

\section{Material and Methods}

Specimens were mounted under a cover slip in Hoyer's solution, and were studied under a Leica Digital Module (DM 2500) microscope. Photographs were taken under a Leica Digital Module R (DMR) microscope using amounted Leica DFC 295 digital camera, and were enhanced with Photoshop CS4 (Adobe Inc.). All specimens are deposited in the Apterygota Section, Zoological Survey of India (ZSI), Kolkata.
Abbreviations: $\mathrm{Abd}=$ abdominal segment, Ant $=$ antennal segment, $\mathrm{Mac}=$ macrochaetae, $\mathrm{P} . \mathrm{A} \cdot \mathrm{O}=$ post antennal organ, $\mathrm{Th}=$ thoracic segment, VT- ventral tube, ms-microsensillum, s-sensillum, Mac-macrosetae, ccommon setae, $\mathrm{p}$-row-posterior row of tergal setae, $\mathrm{px}-$ group of proximal setae, bm-group of basomedial setae, App. an. = Appendices anales, ZSI = Zoological Survey of India, (Kolkata).

Family ENTOMOBRYIDAE Schäffer, 1896

Subfamily ENTOMOBRYINAE Schäffer, 1896

Genus Calx Christiansen, 1958

1958. Calx Christiansen Bull. Mus. Comp. Zool. Harv.

Univ., 118: 437-545

Type species: Entomobrya (Drepanura) sabulicola Mills, 1931

Calx Christiansen, 1958 is a new world scale less Entomobryinae genus with falcate mucro; head with $8+8$ eyes; large macrochaetae bases present on anterior margin of thorax; mucronal basal spine absent, claw with four inner teeth (Christiansen, 1958). So far, four species have been described all over the world (Bellinger et al., 2017) and the genus Calx is recorded from India for the first time with a description of new species Calx kailashi n. sp. A checklist of world species of Calx as reference to their distribution in India and the world is provided.

\section{* Author for correspondence}


1. Calx sabulicola (Mills, 1931). It was recorded from N. North America, S. North America, Pacific North America.

2. Calx cubensis (Folsom, 1927). It was recorded from Caribbean mainland, Antillean and S. Florida.

3. Calx luthuli Rapoport and Rubio, 1968. It was recorded from Cerro El Pajonal, Antofagasta, Steppe tall, Chile (Andean).

4. Calx neryi Soto-Adames, 2002. It was recorded from Antillean and S. Florida

5. Calx kailashi n. sp.

A new species, Calx kailashi n. sp. is described from Panvasba Nallah, Koderma Wild Life Sanctuary, Koderma district, Jharkhand, India.

\section{Key to the world species of the genus Calx}

1. Body with dark pigment patches ...................................2

- Body without dark pigment patches ..............................4

2. Apical sense organ of Ant.III with two small rods..... sabulicola

- Apical sense organ of Ant.III with more than two small rods...

3. Internal ungual paired teeth, close to the middle of the claw. neryi

- Internal ungual paired teeth, two third distal of the claw ...... kailashi n. sp.

4. Unguis without lateral teeth. Tenent hair absent .luthuli

- Unguis with a pair of long, sharp lateral teeth. Tenent hair long and strong cubensis

\section{Calx kailashi sp. nov}

(Plate 1, Figures- 1-22, Table 1 and 2)

Type material: Holotype: male on slide, INDIA, Jharkhand, Panvasba Nallah, East side of Koderma Wild Life Sanctuary, district Koderma, Altitude 389 meters, Latitude $24^{\circ} 29^{\prime} 23.2^{\prime \prime}$ North and $85^{\circ} 36^{\prime} 41.3^{\prime \prime}$ East, date 01.xii.2012, coll. G. P. Mandal (Registration No. 1931 / H14) deposited in the National Zoological Collection, Zoological Survey of India, (Kolkata). Paratypes: 1 example on slide (dissected), same data as Holotype (Registration No. 1932 / H14) and 30 examples in ethyl alcohol, same data as Holotype (Registration No. 1933 / H14) deposited in the National Zoological Collection, Zoological Survey of India, (Kolkata).

Description: Body length up to $1.32 \mathrm{~mm}$ (excluding appendages).

Colour-pattern: Back ground colour yellow-orange, dark violet pigment present in fresh specimens (Figure 1) but in preserved specimens pigments are dark blue (Figure 2). Antennae moderately and uniformly dark except base of each segment. Eye patches dark, an irregular patches below eye to mid-dorsal margin of head; prothorax with anterior portion with small patches, meso and metathorax with dark pigmented patches and spots, posterior margin darker than anterior (Figure 3). Ventrally yellowish in colour, fifth and sixth abdominal segments laterally with pigmented patches (Figure 4). Furcula without pigment. Thorax II to Abd. IV laterally dark pigmented, Th.II to Abd.IV forming an irregular median transverse band and patches (Figures 1-3). Legs base yellow and mid-dorsal and lateral edges dark. Abd.V with dark blue band in midline. Abd. VI totally dark blue.

Antennae: The antennae approximately 2.32 times as long as cephalic diagonal; the ratio of antennal segments I: II: III: IV= 1: 1.8: 1.5: 2.5 (Figure 5). Antennal segments sub cylindrical in shape and sub equal in diameter. Apex of Ant. IV with two apical bulb in two different sizes, distinctly not sub apical, and one distinct pin setae, two small smooth setae (Figure 6). Apical sense organ of third segment of four small rod shaped sensillae (Figure 7).

Head: Head more or less oval, 1.19 times as long as broad, outer labral papillae rounded and five smooth ciliate setae present (Figure 8). Labial appendages with clearly differentiated external setae of normal size present (Figure 9). Eyes 8+8, H smaller than G, 2 large multilaterally ciliate setae arise from eye patch (Figure 10). Cephalic macrochaetae and anterior type 5 setae as shown in Figure 11. 
Clothing: Normal five types of setae present, type 1 setae very broad, long, sharpely expended basally and apex truncate type, predominant on head, Thorax II, III and Abd. I to III. All tergal macrchaetae truncate. Setae of type 5 acuminate for apical two thirds of length, slightly expended medially. Coarsely multilaterally ciliate setae present on head, thorax and abdomen. Bothriotrichia present on head, thorax and abdomen (Figure 12).

Thorax and Abdomen: Relative length index of thoracic segments II: III = 1.6: 1 . Relative length index abdominal segments I: II: III: IV: V: VI = 1: 1.2: 1.1: 5.6: 1.3: 0.6. Chaetotaxy of Th.II- III and Abd. I- III are shown in Figure 13 and Figure 14. Rami of retinaculum with quadridentate; corpus with one long, broad, inner serrated, truncate seta (Figure 15).

Legs: Trochanteral organ with $12-15$ smooth triangular setae (Figure 16). Metatibiotarsi proximally with 5 long multilaterally ciliate setae (Figure 17). Unguis with four inner teeth, inner ungual paired teeth two-third distal of the claw (Figure 18). Unguiculus lanceolate. Unguis and unguiculus without internal ciliation. Tenent hair as long as unguiculus, slender and acuminate.

Furcula and genital plate: Ratio of Manubrium: Dens: Mucro $=1:$ 1.69:0.02. Furcula with great number of multilaterally ciliate setae present on manubrium and both sides of dens. Manubrium with 38-40 multilaterally ciliate setae present on the dorsal side (Figure 19). Dens deeply crenulated. Mucro very small and short (Figure 20). Male genital plate with 10 papillae, 10 angular setae, 6 pegs and 6 normal setae (Figure 21).

Biology: In Jharkhand, found in dry habitats near Panvasba Nallah where the big rock covered with semi decomposed leaf litters, at an altitude 389 meters of elevation and coordinates between $24^{\circ} 29^{\prime} 23.2^{\prime \prime} \mathrm{N}$ latitude and longitude $85^{\circ} 36^{\prime} 41.3^{\prime \prime}$ E. Soil is micacious type(containing particles of mica) and sandy in texture. The forest is tropical dry deciduous type and dominated by tall trees like - Terminalia arjuna, Shorea robusta, Tectona grandis and different types of herbs and shrubs like - Digitaria marginata, D. royleana, Euphorbia hirta and Lantena camera etc. (Figure 22).
Etymology: The new species is named after Dr. Kailash Chandra, Director of the Zoological Survey of India for his keen interest and encouragement in my study.

Discussion: Among the species of New world scale less Entomobryinae with falcate mucro only Calx neryi is yellow and orange with Th. 3 and Abd. 3 uniformly black (Soto-Adames, 2002). Calx luthuli is prussian blue coloration throughout the body, head, antennae, legs and manubrium (Rapoport and Rubio, 1968). Calx cubensis is white, rather scantily marked with blue (Folsom, 1927). Calx sabulicola is dark blue to purple pigment \& background yellow to dull gray (Christiansen, 1958). The new species Calx kailashi $\mathrm{n}$. sp. is also yellow-orange background and dark blue pigment patches throughout the body in preserved specimens, but in fresh specimens dark violet in colour. The dorsal macrochaetotaxy of the trunk of Calx kailashi n. sp. is more $(26,27,14,14,12$, on Th. 2- Abd. 3) setae and differs markedly from the chaetotaxy of C. sabulicola and C. neryi. The unguis of Calx kailashi $\mathrm{n}$. sp. resembles that of C. neryi but differs in the position of the dorsal tooth, which is inserted on the two third distal of the claw. The sensillae of third antennal segment are small rods shaped without blunt, but are short blunt rods in $C$. neryi. The shape of the apical bulb of Ant. 4 is differs from C. neryi and $C$. sabulicola. Male genital plate of Calx kailashi n.sp. is having 10 papillae, 10 angulur setae, 6 pegs and 6 normal smooth setae and differs markedly from $C$. neryi and $C$. sabulicola. The new species could be easily distinguished from all the known species of the genus by the presence of outer labral papillae rounded and five smooth ciliate setae, labial appendages with clearly differentiated external seta, male genital plate, and other characters shown in Table 1.

Remarks: The colour pattern and pigment structure of Calx kailashi $\mathrm{n}$. sp. is nearer to Calx sabulicola but strongly differs with presence of an external differentiated seta on the labial appendages, labral papillae with five smooth ciliate setae, male genital plate having different types of setae, pegs and papillae, number of dorsal macro chaetae of Th. II- Abd. III is more and unguis and unguiculus without internal ciliations and other characters shown in Table 2. The female is larger than male. 
Table 1. Comparison of Calx kailashi n. sp. with other members of the genus

\begin{tabular}{|c|c|c|c|c|c|c|}
\hline $\begin{array}{l}\text { Sl. } \\
\text { No }\end{array}$ & Characters & Calx sabulicola & Calx cubensis & Calx luthuli & Calx neryi & Calx kailashi n. sp. \\
\hline 1 & Body length & $2.5 \mathrm{~mm}$ & $1.4 \mathrm{~mm}$ & $1.4 \mathrm{~mm}$ & $1.1 \mathrm{~mm}$ & $1.32 \mathrm{~mm}$ \\
\hline 2 & Colouration & $\begin{array}{l}\text { Background yel- } \\
\text { low to dull grey; } \\
\text { pigmented dark } \\
\text { blue to purple, } \\
\text { varied in distribu- } \\
\text { tion but generally } \\
\text { in irregular bands } \\
\text { \& patches. }\end{array}$ & $\begin{array}{l}\text { White, rather scanty } \\
\text { marked with blue \& } \\
\text { large specimens have } \\
\text { often a yellowish tinge. } \\
\text { Head with a little lateral } \\
\text { pigment and a pair of } \\
\text { spots or a transverse } \\
\text { mark in front of the eye. } \\
\text { Mesonotum \& metano- } \\
\text { tum bordered laterally } \\
\text { with pigments. }\end{array}$ & $\begin{array}{l}\text { Prussian blue } \\
\text { colour throughout } \\
\text { the body, head, } \\
\text { antennae, legs \& } \\
\text { manubrium. Only } \\
\text { dens lack pigmen- } \\
\text { tation. }\end{array}$ & $\begin{array}{l}\text { Background } \\
\text { colour yel- } \\
\text { low-orange, } \\
\text { more intense on } \\
\text { head anterior to } \\
\text { the eyes and up } \\
\text { to Ant. II. Th. } 3 \\
\text { and Abd. } 3 \text { uni- } \\
\text { formly black. }\end{array}$ & $\begin{array}{l}\text { Back ground co- } \\
\text { lour yellow-orange, } \\
\text { pigments are dark } \\
\text { blue throughout the } \\
\text { body forming irreg- } \\
\text { ular band \& patches. } \\
\text { Antennae dark except } \\
\text { each base. }\end{array}$ \\
\hline 3 & $\begin{array}{l}\text { Apex of Ant.3 } \\
\text { \& Ant. } 4\end{array}$ & $\begin{array}{l}\text { Apical sense or- } \\
\text { gan of third Ant. } \\
\text { segment of two } \\
\text { small rods. An- } \\
\text { tennal apical bulb } \\
\text { double, distinctly } \\
\text { sub apical. }\end{array}$ & Unknown & $\begin{array}{l}\text { Apical sense organ } \\
\text { of third aetennal } \\
\text { segment are fan or } \\
\text { leave-shaped. }\end{array}$ & $\begin{array}{l}\text { Apex of Ant. } 4 \\
\text { with } 3 \text { short } \\
\text { truncates sensil- } \\
\text { lae \& an unlobed } \\
\text { bulb } 3 \text { short } \\
\text { blunt rods on } \\
\text { Ant.3. }\end{array}$ & $\begin{array}{l}\text { Apical sense organ of } \\
\text { third antennal seg- } \\
\text { ment of four small rod } \\
\text { shaped sensillae. Apex } \\
\text { of Ant. IV with two } \\
\text { apical bulb and one } \\
\text { distinct pin setae. }\end{array}$ \\
\hline 4 & $\begin{array}{l}\text { Inner ungual } \\
\text { teeth }\end{array}$ & $\begin{array}{l}\text { Internal ungula } \\
\text { teeth three-fourth } \\
\text { of distance from } \\
\text { base to apex. }\end{array}$ & $\begin{array}{l}\text { Ungual teeth one fourth } \\
\text { from the base. }\end{array}$ & $\begin{array}{l}\text { Internal ungula } \\
\text { teeth are very } \\
\text { close together and } \\
\text { displaced to the } \\
\text { distal third of the } \\
\text { claw. }\end{array}$ & $\begin{array}{l}\text { Ungual paired } \\
\text { teeth, close to } \\
\text { the middle of the } \\
\text { claws. }\end{array}$ & $\begin{array}{l}\text { Ungual paired teeth, } \\
\text { two third distal of the } \\
\text { claw. }\end{array}$ \\
\hline 5 & Tenent hair & $\begin{array}{l}\text { Tenent hair acum- } \\
\text { inate. }\end{array}$ & $\begin{array}{l}\text { Tenent hair long, strong } \\
\text { \& clavate. }\end{array}$ & Tenent hair absent. & $\begin{array}{l}\text { Tenent hair two } \\
\text { times larger than } \\
\text { ventral smooth } \\
\text { setae \& acumi- } \\
\text { nate. }\end{array}$ & $\begin{array}{l}\text { Tenent hair as long } \\
\text { as unguis, slender \& } \\
\text { acuminate. }\end{array}$ \\
\hline 6 & $\begin{array}{l}\text { Trochanteral } \\
\text { organ }\end{array}$ & $\begin{array}{l}\text { Trochanteral or- } \\
\text { gan irregular with } \\
\text { a few scattered } \\
\text { large setae. }\end{array}$ & $\begin{array}{l}\text { Trochanteral organ } \\
\text { absent. }\end{array}$ & $\begin{array}{l}\text { Trochanteral } \\
\text { organ absent. }\end{array}$ & $\begin{array}{l}\text { Trochanteral } \\
\text { organ with 6-9 } \\
\text { smooth traingu- } \\
\text { lar setae. }\end{array}$ & $\begin{array}{l}\text { Trochanteral organ } \\
\text { distinct, with } 12-15 \\
\text { smooth triangular } \\
\text { setae. }\end{array}$ \\
\hline 7 & $\begin{array}{l}\text { Male genital } \\
\text { plate }\end{array}$ & $\begin{array}{l}\text { Fourteen (14) } \\
\text { short setae of } \\
\text { similar shape, all } \\
\text { are acuminate }\end{array}$ & Unknown & Unknown & $\begin{array}{l}\text { Male genital } \\
\text { plate with } 12 \\
\text { papillae, } 10 \\
\text { angular setae, } 2 \\
\text { pegs \& } 4 \text { small } \\
\text { smooth seta }\end{array}$ & $\begin{array}{l}\text { Male genital plate with } \\
10 \text { papillae, } 10 \text { angular } \\
\text { setae, } 6 \text { pegs \& } 6 \text { small } \\
\text { smooth setae. }\end{array}$ \\
\hline 8 & $\begin{array}{l}\text { Dorsal mau- } \\
\text { brial setae }\end{array}$ & Unknown & $\begin{array}{l}\text { Short clavate fringed } \\
\text { setae are present. }\end{array}$ & Unknown & $\begin{array}{l}\text { '3' ciliate setae \& } \\
\text { '2' pseudopores } \\
\text { near base of } \\
\text { dentes. }\end{array}$ & $\begin{array}{l}\text { 38-40 multilaterally } \\
\text { ciliate setae present. }\end{array}$ \\
\hline 9 & Mucro & $\begin{array}{l}\text { Mucro with tooth } \\
\text { heavy \& short. }\end{array}$ & $\begin{array}{l}\text { Mucro short and stout } \\
\text { strongly rounded } \\
\text { ventrally, falcate, with a } \\
\text { single stout apical hook. }\end{array}$ & $\begin{array}{l}\text { Mucro falcate, } \\
\text { without basal } \\
\text { spine. }\end{array}$ & $\begin{array}{l}\text { Mucro falcate, } \\
\text { without basal } \\
\text { spine. }\end{array}$ & $\begin{array}{l}\text { Mucro falcate, short, } \\
\text { without basal spine. }\end{array}$ \\
\hline
\end{tabular}


Table 2. Discriminating characters of Calx sabulicola and Calx kailashi n. sp

\begin{tabular}{|c|c|c|c|}
\hline Sl.No & Characters & Calx sabulicola & Calx kailashi n. sp. \\
\hline 1 & Body length & Up to $2.5 \mathrm{~mm}$ & Up to $1.32 \mathrm{~mm}$ \\
\hline 2 & Colouration & $\begin{array}{l}\text { Background yellow to dull grey; pigment dark blue } \\
\text { to purple, varied in distribution but generally in } \\
\text { irregular bands \& patches. Second \& third antennal } \\
\text { segments with a single line of small oval pegs. }\end{array}$ & $\begin{array}{l}\text { Back ground colour yellow-orange, } \\
\text { pigments are dark blue throughout the } \\
\text { body, formed irregular bands \& patches. } \\
\text { Antennae dark except each base. }\end{array}$ \\
\hline 3 & Outer labral papillae & $\begin{array}{l}\text { Labral papillae with outer pair rounded \& lacking } \\
\text { setae. }\end{array}$ & $\begin{array}{l}\text { Labral papillae with outer pair rounded \& } \\
\text { ' } 5 \text { ' smooth ciliate setae. }\end{array}$ \\
\hline 4 & $\begin{array}{l}\text { External differentiated } \\
\text { setae on labial append- } \\
\text { ages }\end{array}$ & Absent & $\begin{array}{l}\text { One normal external differentiated setae } \\
\text { present. }\end{array}$ \\
\hline 5 & Apex of Ant.IV & $\begin{array}{l}\text { Antennal apical bulbs double; distinctly sub apical, } \\
\text { without pin setae. }\end{array}$ & $\begin{array}{l}\text { Antenna with two apical bulbs, distinctly } \\
\text { not sub apical and one distinct pin setae. }\end{array}$ \\
\hline 6 & Apex of Ant. III & $\begin{array}{l}\text { Apical sense organ of third segments of two small } \\
\text { rods. }\end{array}$ & $\begin{array}{l}\text { Apical sense organ of third segment of } \\
\text { four small rods. }\end{array}$ \\
\hline 7 & Body setae & $\begin{array}{l}\text { Setae of Type 1, very broad, sharply expanded } \\
\text { basally, slightly so at apex. Setae of type five acum- } \\
\text { inate for apical two thirds of the length, slightly } \\
\text { expanded medially. }\end{array}$ & $\begin{array}{l}\text { Setae of Type 1, broad, robust, sub cy- } \\
\text { lindrical in shape, fine serration present } \\
\text { inside the setae. Type five medium to } \\
\text { large size, slender multilaterally ciliate, } \\
\text { acuminate, present throughout the body. }\end{array}$ \\
\hline 8 & Trochanteral organ & $\begin{array}{l}\text { Trochanteral organ irregular with a few scattered } \\
\text { large setae. }\end{array}$ & $\begin{array}{l}\text { Trochanteral organ distinct, with } 12-15 \\
\text { smooth triangular setae present. }\end{array}$ \\
\hline 9 & Ungual internal teeth & Three-fourth of distance from base to apex. & Two-third of distance from base to apex. \\
\hline 10 & Dorsal manubrial setae & Unknown. & 38-40 multilaterally ciliate setae present. \\
\hline 11 & Male genital plate & $\begin{array}{l}\text { Male genital plate with fourteen (14) short setae of } \\
\text { similar shape, all are acuminate }\end{array}$ & $\begin{array}{l}\text { Male genital plate with } 10 \text { papillae, } 10 \\
\text { angular setae, } 6 \text { pegs \& } 6 \text { small smooth } \\
\text { setae. }\end{array}$ \\
\hline 12 & Mucronal tooth & Mucro with tooth heavy and short & Mucro with tooth short \& small. \\
\hline 13 & $\begin{array}{l}\text { Lasiotrichia on anterior } \\
\text { margin of thorax \& } \\
\text { head }\end{array}$ & $\begin{array}{l}\text { Single row of lasio-trichia on anterior margin of } \\
\text { thorax \& head. }\end{array}$ & $\begin{array}{l}\text { Multiple rows of lasio-trichia on anterior } \\
\text { margin of thorax \& head. }\end{array}$ \\
\hline 14 & $\begin{array}{l}\text { Unguis \& unguiculus } \\
\text { with internal ciliations. }\end{array}$ & Unguis \& unguiculus with internal ciliation. & $\begin{array}{l}\text { Unguis \& unguiculus without internal } \\
\text { ciliation. }\end{array}$ \\
\hline
\end{tabular}

Family ISOTOMIDAE Börner, 1913

Subfamily PROISOTOMINAE Stach, 1947

Genus Folsomia Willem, 1902

1902. Folsomia Willem, Ann. Soc. Ent. Belg. 46: 275-283

Type species: Folsomia candida Willem, 1902

Folsomia Willem, 1902 is one of the largest genera in the family Isotomidae. It differs from the other Isotomidae in the following characters: the last three abdominal segments fused, PAO present, well developed, but rather short furcula, retinaculum with $4+4$ teeth and a single large seta, anal spines absent (Ding et al., 2006). So far, about 177 species have been described all over the world (Bellinger et al., 2017) and F. baijali Prabhoo, 1972 is found to be endemic to India. A checklist of Indian species, of Folsomia as reference to their distribution in India and the World is provided. 
1. F. fimetaria (Linnaeus, 1758). It was recorded from Dodabetta, Nilgiris, Tamil Nadu of India and from Arctic and Sub-arctic, Europe, North Eurasia, Sino-Japanese, Himalayan, West and Central Asia, Mediterranean, Macronesian, North America, Caribbean mainland, Antillean and S. Florida.

2. F. santokhi (Baijal, 1958). It was recorded from North Slope of Pir Panjal Range Lahaul (upper Chandra Valley), opposite Kulti Nal, 3675m, Himachal Pradesh, India and Himalaya.

3. F. baijali Prabhoo, 1971. It was only recorded from Vandiperiyar, Kerala, India.

4. F. octoculata Handschin, 1925. It was recorded from Nilgiris, Tamil Nadu of India and Northern Eastern Asia\& Hawaii Island, Himalaya, Sino-Japanese and African-Indian desert.

5. F. arunachalensis n. sp.

A new species, Folsomia arunachalensis n. sp. is described here from Lower Dibang Valley District, 65, Mayudia, Arunachal Pradesh, India.

\section{Key to the Indian species of the genus Folsomia}

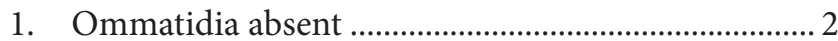

- Ommatidia present ........................................................... 4

2. Manubrium with fewer than 10 anterior setae .......... 3

- Manubrium with 17-18 anterior setae arunachalensis n. sp.

3. Manubrium with $1+1$ anterior setae. baijali

- Manubrium with 4+4 anterior setae................ fimetaria

4. With $6+6$ or more ommatidia .......................... santokhi

- With 4+4 ommatidia ......................................octoculata

Folsomia arunachalensis sp. nov.

(Plate 2, Figures-1-20, Table 3-4)

Type material: Holotype: Female on slide, INDIA, Arunachal Pradesh, Lower Dibang Valley District, 65 Mayudia, Altitude $2481 \mathrm{~m}$., Latitude $28^{\circ} 14.103^{\prime} \mathrm{N}$ and $95^{\circ} 54.895^{\prime} \mathrm{E}$, date 03.xi.2015, coll. Dilip Mondal (Registration No. 1791/H14) deposited in the National Zoological Collection, Zoological Survey of India, (Kolkata). Paratypes: 1 ex on slide, same data as Holotype
(Registration No. 1792/H14) and 50 exs in ethyl alcohol, same data as Holotype (Registration No. 1793/ H14) deposited in the National Zoological Collection, Zoological Survey of India, (Kolkata).

Description: Body length up to $0.92 \mathrm{~mm}$.

Colour: Ground colour creamy white, no pigmentation and ocelli (Figure 1).

Head: Ommatidia absent. PAO broad, oval shape, without distinct constriction, with 3 guard setae (Figure 2), PAO 1.3-1.4 times as long as width of Ant. I and 2.2 times more than inner edge of claw III. Maxillary palp bifurcated, maxillary outer lobe with 4 sublobal hairs (Figure 3 ). Labral setal formula 4, 5, 4. Labium with 4+4 basomedian setae. Ventral side of head with $4+4$ setae along linea ventralis (ventral grove). Ant. I, II, III respectively with 1, 1, 0 basal microsensilla (bm) and 2, 3, 3 sensilla (s). Ant. IV with weekly differentiated sensilla with apical lobe(Figures 4, 5, 6, 7 ).

Body chaetotaxy: Macroseta (Mac) obviously longer than ordinary seta. Sensillum (s) thinner-walled, shorter and more slender than common setae. Microsensillum (ms) thick-walled and shorter than common seta and sensillum (Figures 8, 9, 10). Formula of body macrosetae Th-II, ThIII, Abd-I, II, III, V as 1, 1, 0, 1, 1, 5 per half tergum, longest on last 3 abdominal segment 2.77 times length of mucro. Sensillar and micro-sensillar formula respectively as 4, 3/2, 2, 2, 3, 5 (s) and 1, 1, 0 (ms) (Figures 11, 12, 13). Medial sensilla on all tergites situated within P-row, on Abd. I-III between macrochaeta 1 and 2. Axial setae (common setae along median line on each side) of Th. II-Abd. III: 8-9, 9(10), 8(9), 8. Th. II with 20-22 setae in p-row.

Appendages: Unguis withoutlateral \&inner teeth. Tibiotarsus with many additional setae. Ventral tube with $4+4$ latero distal and 4-5 posterior setae (Figure 14). Retinaculum $4+4$ teeth and 1setae (Figure 15). Tenent hairs absent. Anterior side of manubrium with 18 setae, posteriorly with 4 basal setae, of which 3 apical and 1 middle (Figure 16); dens crenulated, anterior side with 22 setae, in two rows, posterior with 4 setae(Figures 17 and 18) and lateral side of 
dens with 11 setae (Figure 19). Mucro with 2 teeth (Figure 20), ratio of manubrium: dens:mucro as 5.1:8.5:1.

Etymology: The new species is named after the type locality.

Biology: In Arunachal Pradesh, found under the grasses, covered with dung of animals. The area is hilly and difficult terrain, covered with mixed vegetation of semi evergreen forests.

Discussion: Folsomia arunachalensis $\mathrm{n}$. sp. belongs to the $F$. fimetaria group because of abdominal sensilla positioned in the p-row, ventral chaetae on Th.III usually missing and only one pair of macrochaetae present on thoracic segment (Potapov, 2001). The new species could be easily distinguished from all the known species of the genus by the body sensilla being $4,3 / 2,2,2,3,5$; setae on anterior side of manubrium being ' 18 ' and anterior dental setae in two rows containing ' 20 ' and other characters shown in Table 3.
Remarks: All species of the fimetaria group are blind, have no chaetae on ventral side of Abd. III and no or only $1+1$ lateral sens thickened on Abd. V. The two main characters to discern the Folsomia species are ventral setae on the third thoracic segment and number of ventral setae on the distal region of the manubrium. The redescription of F. fimetaria by Lucianez and Simon, 2002 also clearly indicate that the absence of ventral setae on the third thoracic segment and manubrium with $4+4$ ventral setae. The new species could be easily separated from other species in the fimetaria group by its particular body sensilla and chaetotaxy of manubrium and dens. Manubrium with 17 anterior setae arranged in $3+3,3,3-5$ and posterior side of manubrium with 4 setae. Dens with 22 setae in anterior side arranged in two rows, posterior with 4 setae and laterally with 11 setae. Folsomia arunachalensis n. sp. is nearer to F. fimetaria (Linnaeus, 1758) having without pigment and omma, maxillary pulp bifurcate, maxillary outer lobe with 4 sublobal hairs but strongly differs with other characters shown in Table 4.

Table 3. Comparison of Folsomia arunachalensis n.sp. with other member in fimetaria group

\begin{tabular}{|c|c|c|c|c|c|}
\hline SI No. & Species & Omma & $\begin{array}{c}\text { Ventral tube- distal } \\
\text { setae }\end{array}$ & Body sensilla & $\begin{array}{c}\text { Manubrium } \\
\text { anterior setae }\end{array}$ \\
\hline 1 & arunachalensis $\mathbf{n} . \mathbf{s p .}$ & $0+0$ & $4+4$ & $4,3 / 2,2,2,3,5$ & $17-18$ \\
\hline 2 & asiatica Martynova, 1971 & $0+0$ & $5+6$ & $4,3 / 2,2,2,3$ & $5+5$ \\
\hline 3 & baijali Prabhoo, 1971 & $0+0$ & $?$ & $?$ & $1+1$ \\
\hline 4 & bisetosa Gisin, 1953 & $0+0$ & $5+5$ & $4,3 / 2,2,2,3$ & $2+2$ \\
\hline 5 & candida Willem, 1902 & $0+0$ & $9+9$ & $4,3 / 2,2,2,3$ & $16-32$ \\
\hline 6 & cilaita Babenko \& Bulavintsev, 1993 & $0+0$ & $5+5$ & $4,3 / 2,2,2,3,5$ & $3+3$ \\
\hline 7 & cryptophila Potapov \& Babenko, 2000 & $0+0$ & $4+4$ & $4,3 / 2,2,2,3,5$ & $2+2$ \\
\hline 8 & dovernis Fjellberg, 1976 & $0+0$ & $4+4$ & $4,3 / 2,2,2,3,5$ & $1+1$ \\
\hline 9 & fimetaria (Linnaeus, 1758) & $0+0$ & $5+5$ & $4,3 / 2,2,2,3$ & $4+4$ \\
\hline 10 & fimetariodes (Axelson, 1903) & $0+0$ & $5+5$ & $4,3 / 2,2,2,3,5$ & $7+7$ \\
\hline 11 & mofettophila Schulz \& Potapov, 2010 & $0+0$ & $4+4$ & $4,3 / 2,2,2,3,5$ & $2+2$ \\
\hline 12 & kerni Gisin, 1948 & $0+0$ & $?$ & $?$ & $4+4$ \\
\hline 13 & lawrencei Rusek, 1984 & $0+0$ & $3+3$ & $3 / 2,2,2$ & $3+3$ \\
\hline 14 & nivalis (Packard, 1873) & $0+0$ & $5+5$ & $4,3 / 2,2,2,3,5$ & $5+5$ \\
\hline 15 & sparsosetosa Potapov \& Stebaeva, 1997 & $0+0$ & $4+4$ & $4,3 / 2,2,2,3$ & $11-15$ \\
\hline 16 & stella Grow \& Christiansen, 1977 & $0+0$ & $7+7$ & $4,2 / 2,2,1,2$ & $4+3$ \\
\hline
\end{tabular}


Table 4. Discriminating characters of F. fimetaria, and F. arunachalensis n. sp

\begin{tabular}{|l|l|l|}
\hline Characters & F. fimetaria (Linnaeus, 1758) & F. arunachalensis n. sp. \\
\hline Body length & up to $1.4 \mathrm{~mm}$ & up to $0.92 \mathrm{~mm}$ \\
\hline PAO & narrow, as long as width of Ant I or shorter. & $\begin{array}{l}\text { broad, oval shape, } 1.3-1.4 \text { times as long as } \\
\text { width of Ant I. }\end{array}$ \\
\hline Ventral setae on the Th.III segment & none & $1+1$ \\
\hline $\begin{array}{l}\text { Basal microsens }(\mathrm{bm}) \text { and sens(s) of } \\
\text { Ant I, II, III }\end{array}$ & $2,3,0(\mathrm{bm}) \& 2,1,5(\mathrm{~s})$. & $1,1,0(\mathrm{bm}) \& 2,3,3(\mathrm{~s})$. \\
\hline Ventral tube with setae & $5+5$ laterodistal setae \& 5-6 posterior setae. & $4+4$ laterodistal setae \& 4-5 posterior setae. \\
\hline Mac chaetotaxy formula & $1,1 / 3,3,3$ & $1,1,0,1,1,5$ \\
\hline Sensillar formula & $4,3 / 2,2,2,3$ & $4,3 / 2,2,2,3,5$ \\
\hline Manubrium anterior setae & $4+4$ & $17-18$ setae \\
\hline Dens on anterior setae & $18-24$ setae & 22 setae, arranged in two rows \\
\hline Setae on posterior side of dens & 5 setae(3+2) & 4 setae(3+1) \\
\hline
\end{tabular}

Family BOURLETIELLIDAE Borner, 1912

Genus Bourletiella Banks, 1899

1899. Bourletiella Banks, J.N.Y. Ent. Soc. 7: 193-197

\section{Type species: Smynthurus hortensis Fitch, 1863}

Bourletiella Banks, 1899 with large abdomen globular, row 5:1 seta. Ant. IV with large sensillum $P$ on $1^{\text {st }}$ whorl behind the tip, with 2 ventral and 12 tip sensilla. Inner setae of Tita not obliquely truncate. Tita I-III with 3, 3, 2 spatulate setae respectively. All empodium pointed, with lamellae, with short and pointed subapical filaments (Bretfeld, 1999). So far, about 31 species have been described all over the world (Bellinger et al., 2017) and Bourletiella captis Baijal and Mathur, 1969 is found to be endemic to India. A checklist of Indian species, of Bourletiella as reference to their distribution in India and the World is provided.

1. Bourletiella captis Baijal and Mathur, 1969. It was recorded from Manali, Himachal Pradesh.

2. Bourletiella arvalis (Fitch, 1863). It was recorded from Kashmir, India and Himalaya, Australia, Europe, Sino- Japanese, Canada, U.S.A., New Zealand.

3. Bourletiella hortensis (Fitch, 1863). It was recorded from Manali, Himachal Pradesh and widely distributed from various parts of the world such as Europe, Australia, Japan, Canada, U.S.A., Russia and Antarctica.

4. Bourletiella meghalayensis $\mathrm{n}$. $\mathrm{sp}$.
A new species, Bourletiella meghalayensis n. sp. is described from East Khasi Hills district of Meghalaya, India.

\section{Key to the Indian species of the genus Bourletiella}

1. Colour entirely yellow with some markings...............2

- Colour blue with or without markings ......................... 3

2. Colour entirely yellow with both pairs of curved clasping spines on dorsal surface of the anal segment of male pointing posteriorly. arvalis

- Colour yellow, marked with blue, antennae completely blue; the pair of clasping organ pointing downwards captis

3. Colour blackish blue, App. an. thin, broad fanlike, apically almost smooth. hortensis

- Colour blue, marked with green and yellow, App. an. narrow, spatula shape, out edge pointed, without serration .Bourletiella meghalayensis n. sp.

Bourletiella meghalayensis sp. nov.

(Plate 3, Figures - 1- 17, Table 5)

Type material: Holotype: Female on slide, INDIA, Meghalaya, Mylliem village, Umiew river, East Khasi Hills

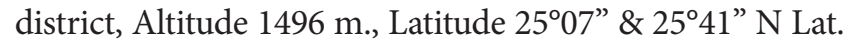
and $91^{\circ} 21^{\prime \prime} \& 92^{\circ} 09^{\prime \prime}$ E Longitude. date 05.iii.2016, coll. E.E.Jehamalar (Registration No. 2048/H14) deposited in the National Zoological Collection, Zoological Survey of India, (Kolkata). Paratypes: Female, 1 ex on slide, same data as 
Holotype (Registration No.2049 /H14); Paratypes: Female, 1 ex on slide, same data as Holotype (Registration No. 2050/ H14); Paratypes: 3 examples on slide (dissected), same data as Holotype (Registration No. 2051-2053 / H14) and 4 exs in ethyl alcohol, same data as Holotype (Registration No. 2054/H14) deposited in the National Zoological Collection, Zoological Survey of India, (Kolkata).

Description: Body length up to $1.36 \mathrm{~mm}$.

Colour pattern: Main colour blue, marked with green and yellow spot on the thorax and large abdomen. Head dark blue, ocelli dark, lighter form in between two ocelli, Ant. I-IV with blue pigment, base of Ant. I pale, all legs are light blue and furcula blue. Thorax and large abdomen deep blue dorsally with green and yellow marking, a big yellow spot present dorsally on large abdomen (Figure 1).

Head: Length of antennae: head diagonal $=1: 5$. Head clothed with short, smooth, plain setae. All setae are uniform in size (Figure 2). Mouth parts shown as in Figure 3.
Antennae: Length ratio of antennal segments I: II: III: IV as 1: 1.7: 2.6:5.1. Ant. I with 3 smooth setae medially (Figure 4). Ant. II with 9-12 setae. Ant.III with two sensillum(s) basally and one micro-sensillum(ms) (Figure 5). Ant. IV with 7 sub segments (Figure 6).

Clothing: Head, Antennae, legs, thorax and abdomen clothed with plain, short, smooth setae.

Legs: Unguis with two inner teeth anterior and medially and one outer tooth medially (Figure 7). Unguiculus very thin without teeth (Figure 8 ). 3 long clavate tenent hair on each foot as long as unguis (Figure 9). Tita II row p: 3 setae (Figure 10). Length of longest setae of Tita III > diameter of Tita (Figure 11).

Furcula and genital plate: Tenaculum with 3 barbs each and without setae (Figure 12). Length ratio of mucro: dens: manubrium as 1: 2.9:1.5. Number of manubrium anterior setae is 5 (Figure 13). Formula of anterior setae of dens $2,1,1,1 \ldots 1$ (Figure 14 ). Mucro with very narrow anterior furrow, basal $2 / 3$ with furrow, mucro with light serration ventrally (Figure 15). Abd.VI dorsally with

Table 5. The differences between Bourletiella hortensis (Fitch, 1863) and Bourletiella meghalayensis n. sp

\begin{tabular}{|c|c|c|}
\hline Characters & Bourletiella hortensis (Fitch, 1863) & Bourletiella meghalayensis n. sp. \\
\hline Colour pattern & $\begin{array}{l}\text { Main colour blackish blue. Head and } \\
\text { large abdomen dorsally more or less pale. }\end{array}$ & $\begin{array}{l}\text { Main colour blue, marked with green and yellow spot on the } \\
\text { thorax and large abdomen. Head dark blue, ocelli dark, lighter } \\
\text { form in between two ocelli, Ant. I-IV with blue pigment, base } \\
\text { of Ant. I lighter, all legs are light blue and furcula blue. Thorax } \\
\text { and large abdomen deep blue dorsally with green and yellow } \\
\text { marking, a big yellow spot present dorsally on large abdomen }\end{array}$ \\
\hline Tita II and Tita III & $\begin{array}{l}\text { Tita II row p: } 3 \text { setae, length of longest } \\
\text { setae of Tita III = diameter of Tita }\end{array}$ & $\begin{array}{l}\text { Tita II row p: } 3 \text { setae, length of longest setae of Tita III > diam- } \\
\text { eter of Tita }\end{array}$ \\
\hline $\begin{array}{l}\text { Unguis and unguic- } \\
\text { ulus }\end{array}$ & $\begin{array}{l}\text { Unguis with one inner tooth and no outer } \\
\text { tooth, Unguiculus lanceolate. }\end{array}$ & $\begin{array}{l}\text { Unguis with two inner teeth anterior and medially and one } \\
\text { outer tooth medially. Unguiculus very thin without teeth. }\end{array}$ \\
\hline $\begin{array}{l}\text { Formula of anterior } \\
\text { setae of dens }\end{array}$ & $\begin{array}{l}\text { Formula of anterior setae of dens } \\
2+1,2,1,1 \ldots 1 \text {. }\end{array}$ & $\begin{array}{l}\text { Formula of anterior setae of dens } \\
2,1,1,1 \ldots .1 \text {. }\end{array}$ \\
\hline Mucro & Mucro with furrow only in basal $1 / 3$. & Mucro with furrow in basal $2 / 3$. \\
\hline App. an. & $\begin{array}{l}\text { App. an. thin, broad, fanlike, apically } \\
\text { almost smooth. }\end{array}$ & $\begin{array}{l}\text { App. an. Narrow, not broad, spatulate, out edge pointed, with- } \\
\text { out serration. }\end{array}$ \\
\hline Body length & $1.8 \mathrm{~mm}$ & $1.36 \mathrm{~mm}$ \\
\hline
\end{tabular}


median crest, setae long (Figure 16). Appendices anales (App. an.) narrow, spatulate shape, out edge pointed, without serration (Figure 17). Ratio of App. An: mucro $=1: 2$.

Etymology: The new species is named after the type locality.

Biology: In Meghalaya, found on the Umiew river bed of East khasi Hill district.

Discussion: The new species from East khasi Hill district of Meghalaya, India can easily distinguished from other known species of Bourletiella by colour pattern, claw structure, Tita II row p:3 setae, and Annal appendages. It is close to Bourletiella hortensis (Fitch, 1863), in having similar type Tita II row p:3 and Ant. IV with 7 sub segments but strongly differ from Bourletiella hortensis in the characteristics given below in the Table 5 .

\section{Summary}

A total of 3 species of Collembola belonging to 3 genera under 3 families Entomobryidae, Isotomidae and Bourletiellidae have been described as new to science from India. The detailed descriptions of each species of Collembola with discussion for difference between closely related species, total numbers of species in the world as well as from India, key to the Indian species and their distribution are also provided.

\section{Importance of Collembola}

Collembola play a significant role in the breakdown of leaf litter along with certain other micro-athropods and consequently aiding in the process of humification. Thus, they play a key role in enhancing soil fertility. They are also known to enrich the organic content of the soil in the form of faecal matter. Collembolans are also increasingly getting their due recognition as bio-indicator of soil conditions. These insects exhibit wide range responses to changes in soil factors. It has also been reported (Mitra, 1993) that collembolan can be used as an index of crop production in an Agro-ecosystem; some of them are minor pests in agriculture.

\section{Acknowledgements}

The author is grateful to the Director, Dr. Kailash Chandra, Zoological Survey of India, Kolkata for giving opportunity to study the materials and laboratory facilities. I am thankful to Shri K. C. Gopi, Scientist-F and Divisional - In - charge Entomology Division for encouragement. Thanks are also due to Dr. A. K. Hazra, ex-Emeritus Scientist, of Zoological Survey of India for encouragement and all staff members of Apterygota Section namely Shri K. K. Suman, Senior Zool. Asstt., Shri K. K. Bhattacharya, Senior Zool. Asstt., and Shri N.C. Maitra, Junior Zoological Assistant and Sri Souradip Roy for their help and co-operation.

\section{References}

Baijal, H.N. 1958. Nival Collembolan from the North-West Himalaya. Proc. Nat. Acad. Sci. Allahabad (India), 28: 349-360.

Baijal, H.N. and Mathur, S.M. 1969. Indian species of Bourletiella Banks (Collembola : Sminthuridae, Sminthurinae). Zool. Anz., 183(3/4): 257-259.

Bellinger, P.F., Christiansen, K.A. and Janssens, F. 1996-2017. Checklist of the Collembola of the World. Available from: http://www. collembola.org/taxa

Bretfeld, G. 1999. Symphypleona. In: Dunger, W. (Ed.), Synopses on Paleartic Collembola. Vol.2., Abdhandlungenund Berichte des Naturkundemuseums Görlitz, 71(1): 1-318.

Christiansen, K.A. 1958. The nearctic members of the genus Entomobrya (Collembola). Bulletin of the Museum of Comparative Zoology at Harvard University, 118: 437-545.

Yufeng, D., Ji, M., and Chen J. 2006. The Chinese Folsomia with a description of a new species (Collembola: Isotomidae). Zootaxa, 1185: 53-59.

Fitch, 1863. Eighth report on the noxius and other insects of the State of the New York. Trans. N. Y. St. Agric. Soc, 22: 657-691.

Folsom, J.W. 1927. Insects of the subclass Apterygota from Central America and the West Indies. Proceedings United States National Museum, 71: 1- 16 .

Handschin, E.1925. Beitrage zur Collembolen fauna der Sundain seln. Treubia, 6: 225 - 270.

Linnaeus, C.1758. Systema Nature. L. Salvius, Copenhagen. Ed. 10. IV + 824pp. 
Maria L.J. and Carlos, J.S. 2002. Redescription of Folsomia fimetaria (Linnaeus, 1758) (Collembola: Isotomidae) and description of Folsomia checae n. sp. from the Iberian Penisula. Redia, 85: 173-182.

Mills, H.B. 1931. New Nearctic Collembola, American Museum Novitates, 464: 1-11.

Mitra, S.K.1993. Effects of continuous cultivation and other agronomic practices on soil micro-arthropods. A unifying concept of Agriculture and Ecology for tropical agro-ecosystem. Rec. zool. Surv. Ind. Occ. paper no. 151: 1-177.

Potapov, M. 2001. Isotomidae. In: Dunger, W. (Ed.), Synopses on Paleartic Collembola. Vol.3., Abdhandlungenund Berichte des Naturkundemuseums Görlitz, 73(2): 1-603.

Prabhoo, N.R. 1971. Soil and litter Collembola of South India. I. Arthropleona. Oriental Insects, 5: 1-46.

Rapoport, E.H. and Rubio, I. 1968. Fauna Collembologica De Chilie II. Acta Biologica Venezuelica, 6(1): 52-67.

Soto-Adames, F.N. 2002. Four new species and new records of springtails (Hexapoda: Collembola) from the US Virgin Islands and Puerto Rico, with notes on the Chaetotaxy of Metasinella and Seira. Caribbean Journal of Science, 38(1-2): 77-105. 


\section{Plate 1}
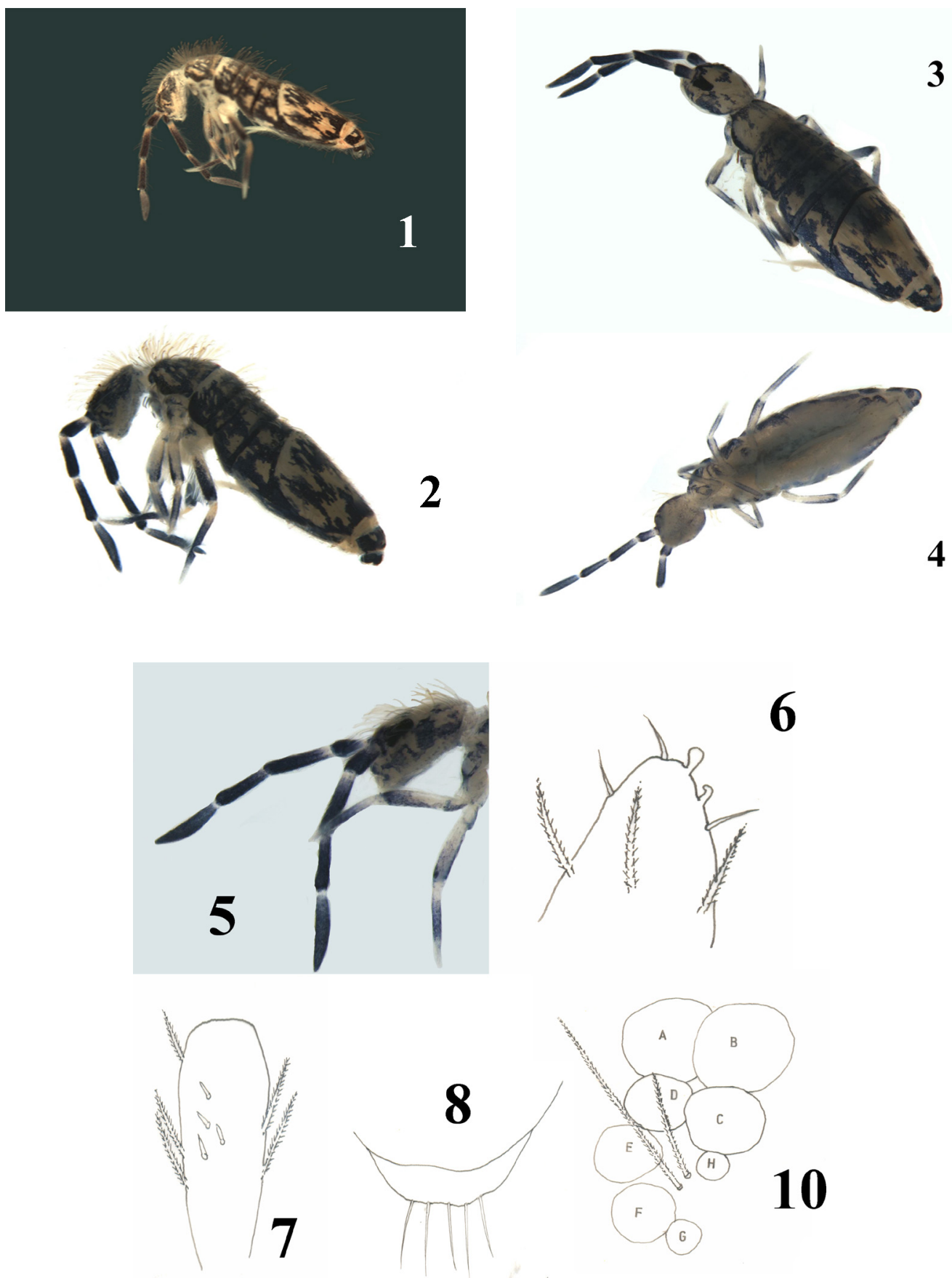

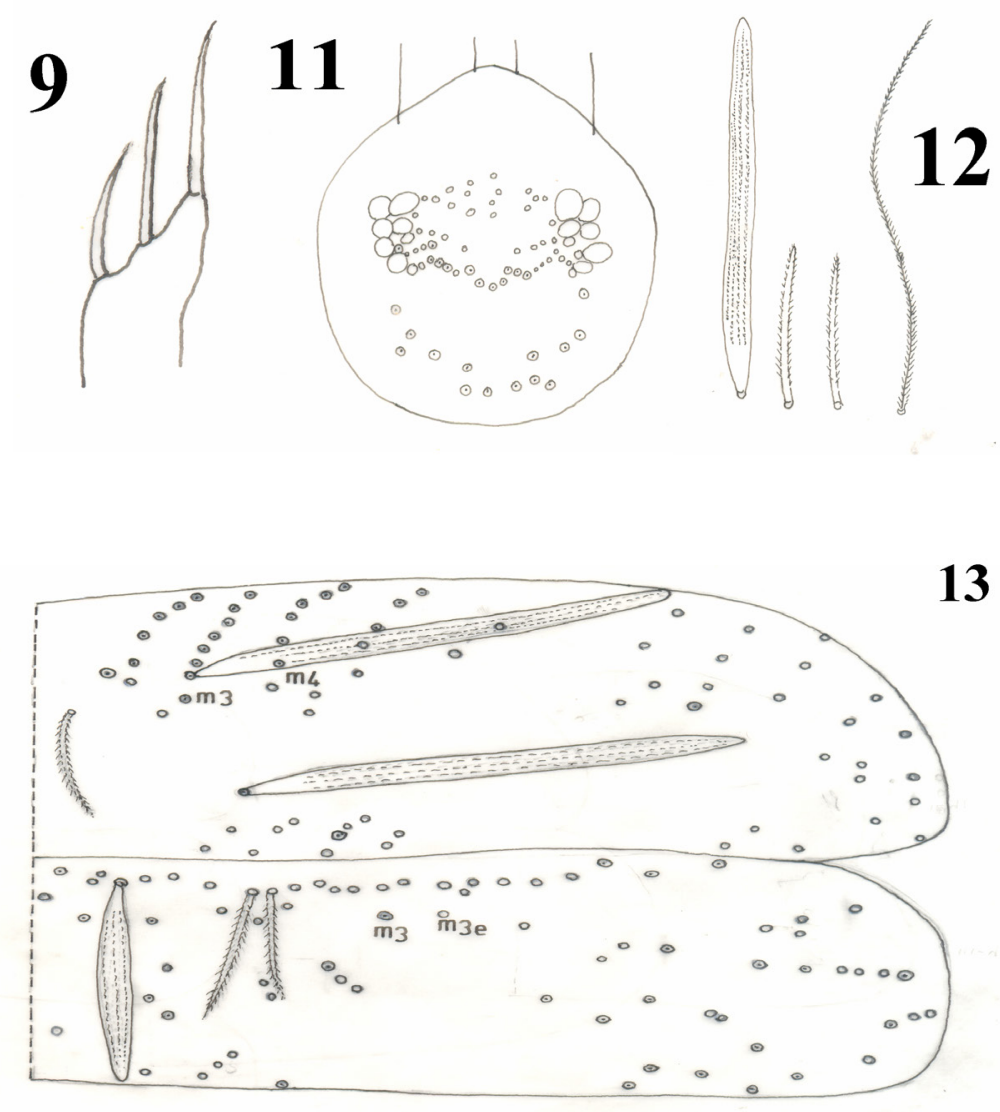

14

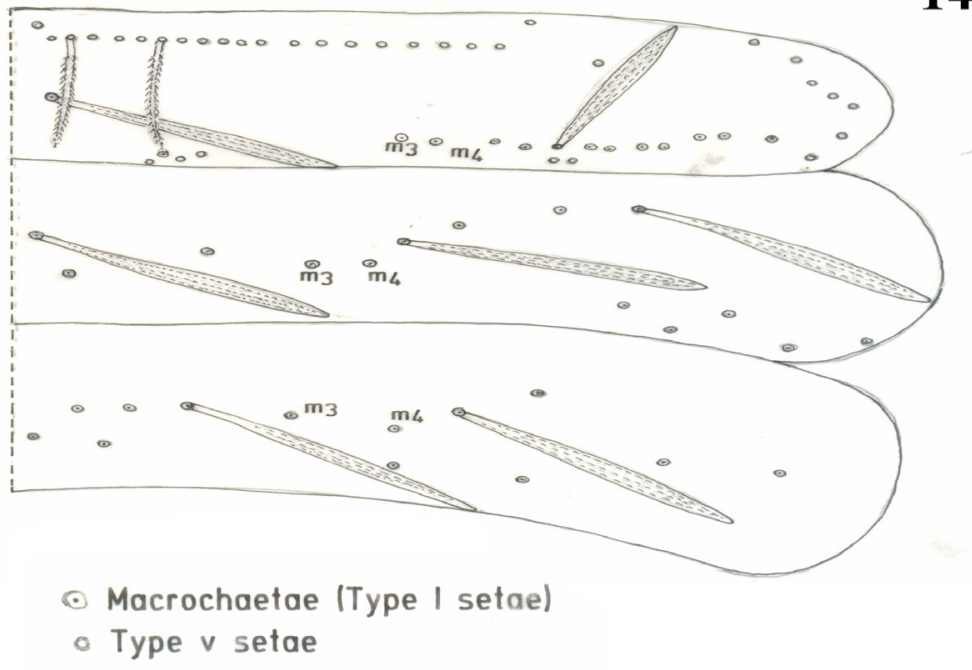




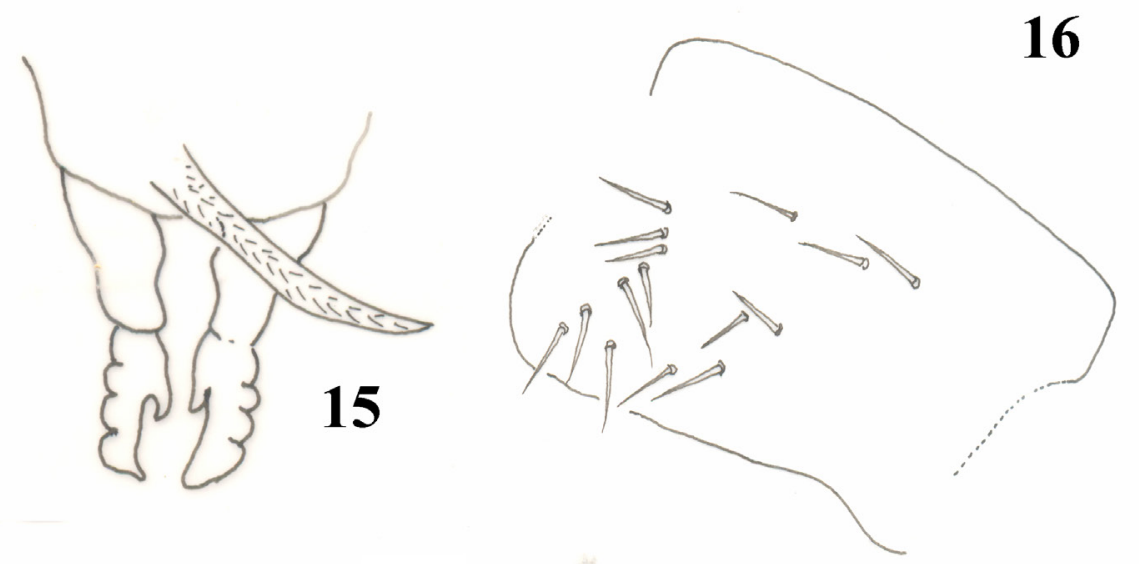

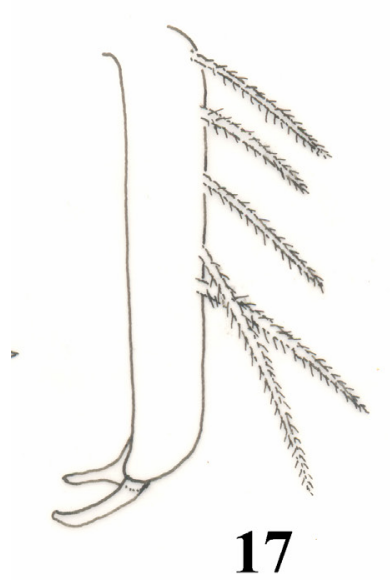

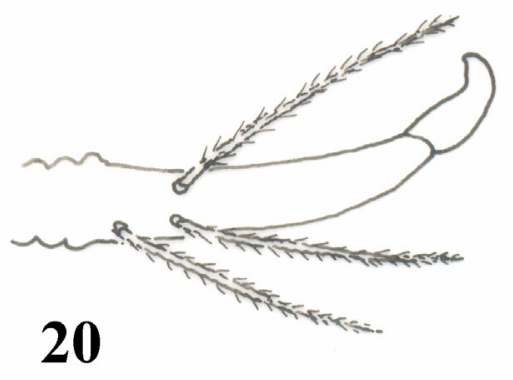

19
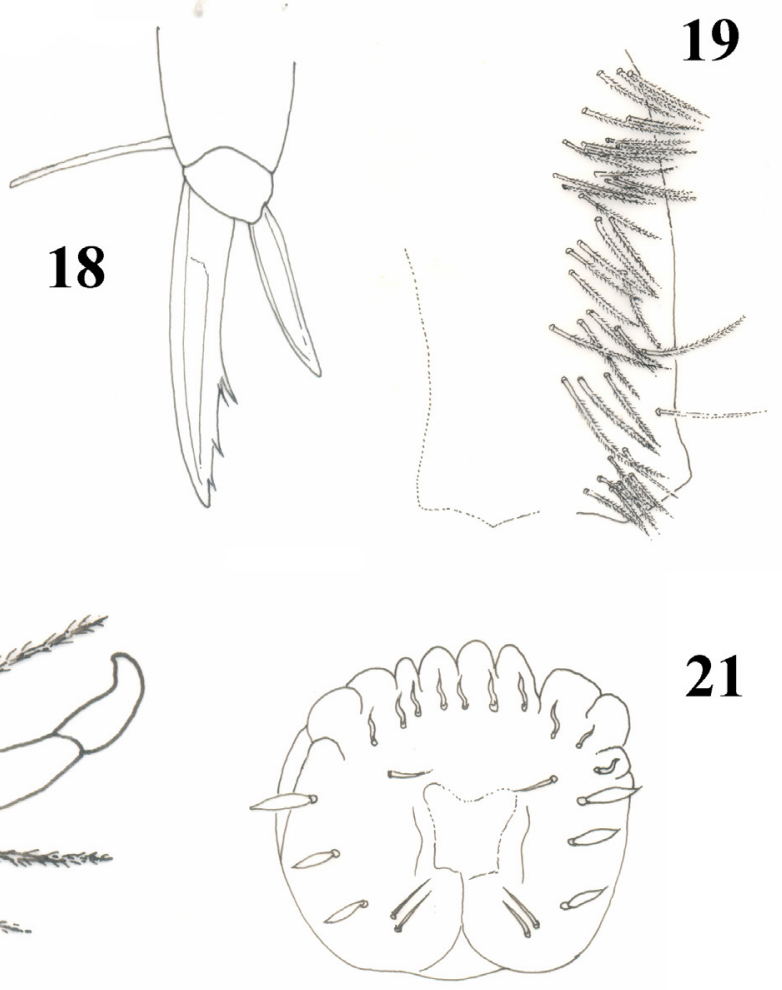


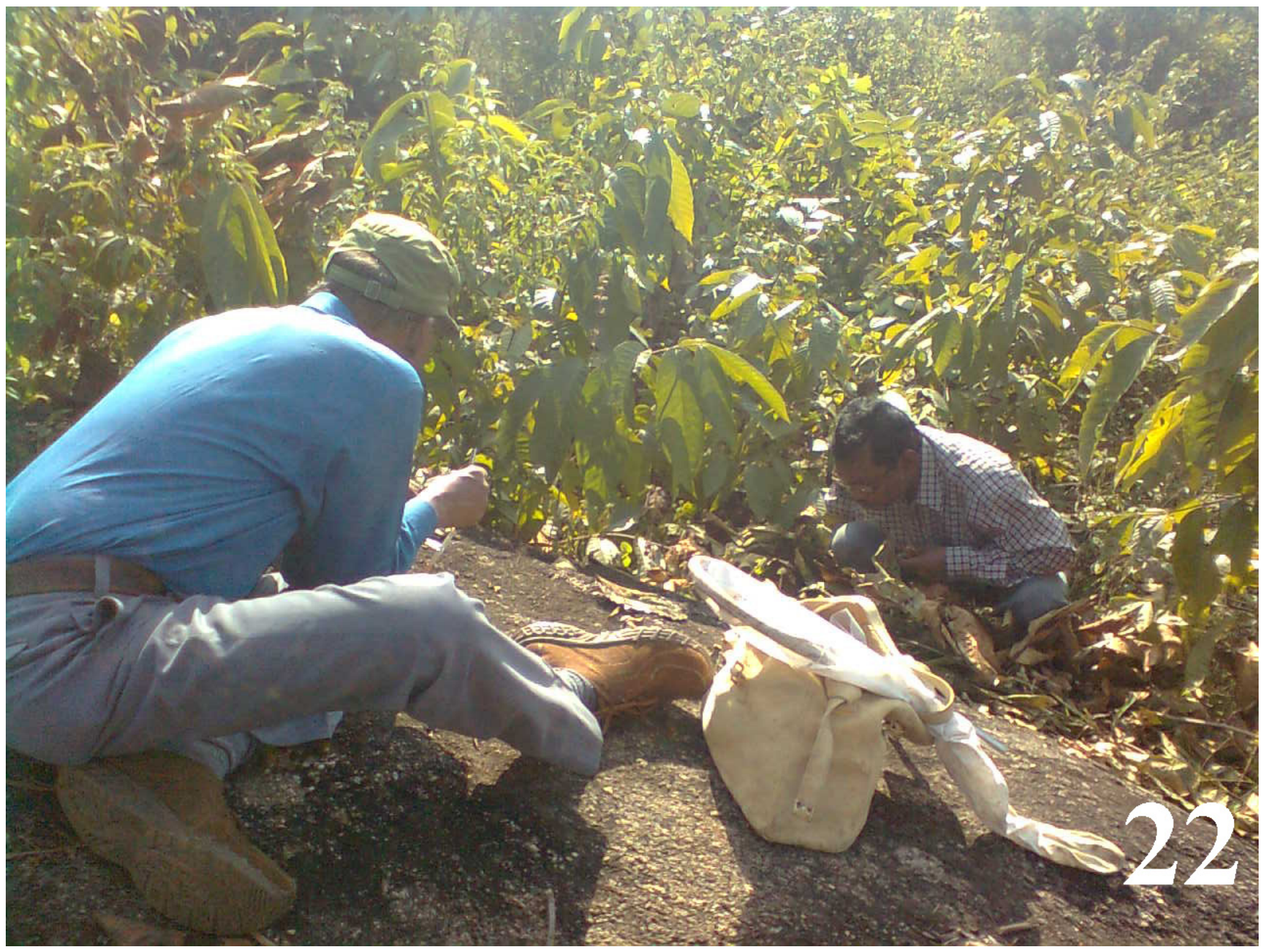

Figures 1-22. Calx kailashi sp. nov. 1. Calx kailashi sp. nov. habitus (lateral view). 2. Calx kailashi sp. nov. habitus (lateral view). 3. Calx kailashi sp. nov. habitus (dorso- lateral view). 4. ventral view. 5. Antenna. 6. Apex of Ant. IV. 7. Apex of Ant.III. 8. Outer labral papillae. 9. differentiated external labial setae. 10. Eyes. 11. Dorsal cephalic chaetotaxy 12. Type of setae. 13. Cheatotaxy of Thorax..II- III. 14. Cheatotaxy of Abd.I-III. 15. Retinaculum. 16. Trochantral organ. 17. Tibiotarsal setae. 18. Hind foot complex. 19. Dorsal setae on Manubrium. 20. Mucro. 21. Male genital plate. 22. Type - locality of Calx kailashi sp. nov. at Panvasba Nallah, East side of Koderma Wild Life Sanctuary, district Koderma, Jharkhand, India. 


\section{Plate 2}
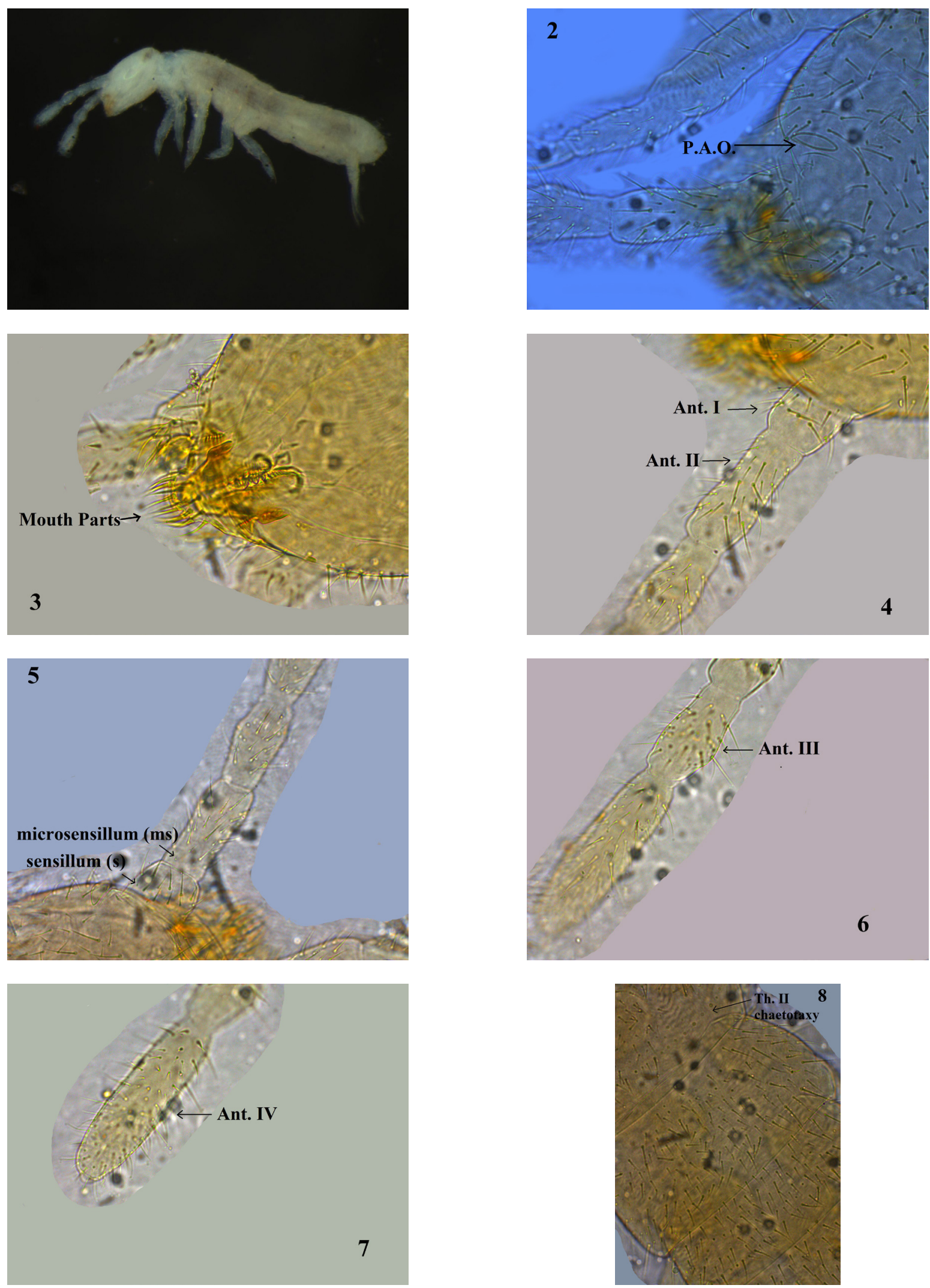

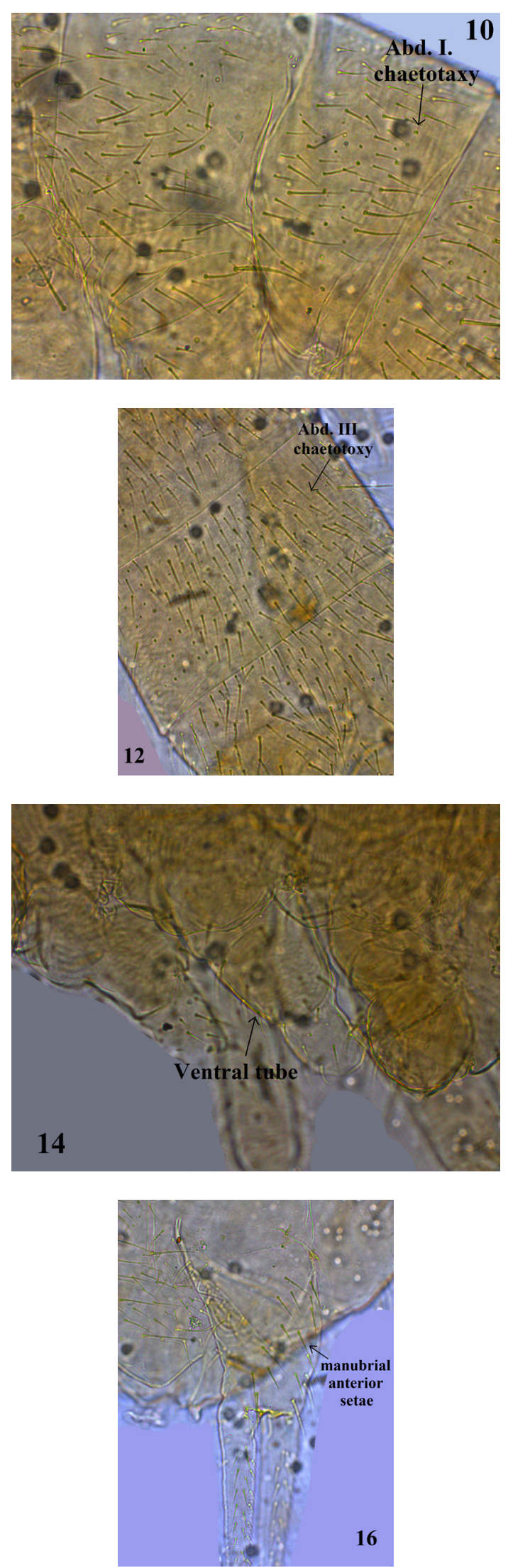
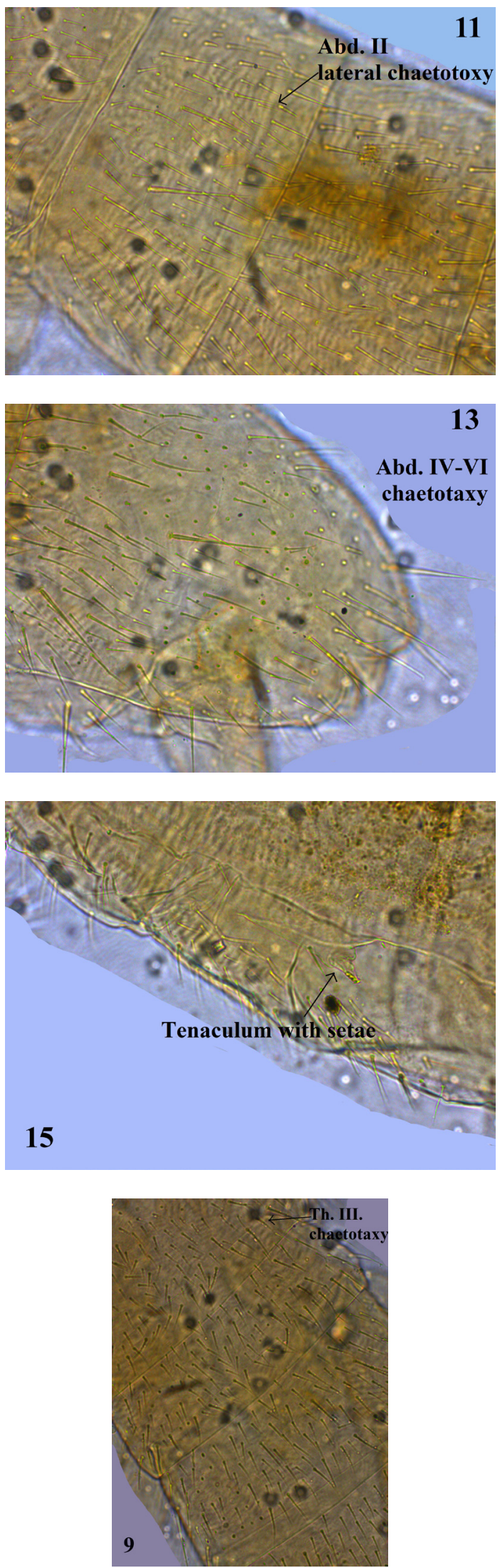

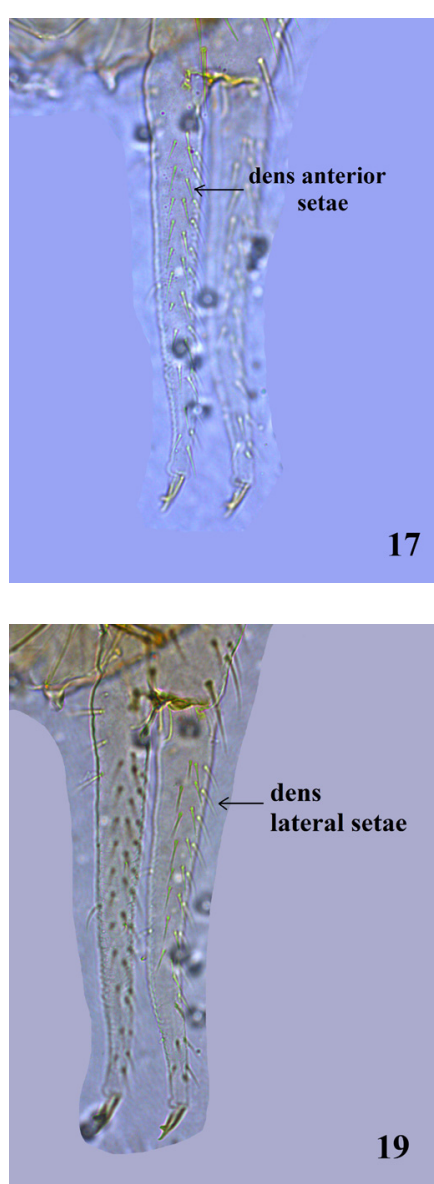
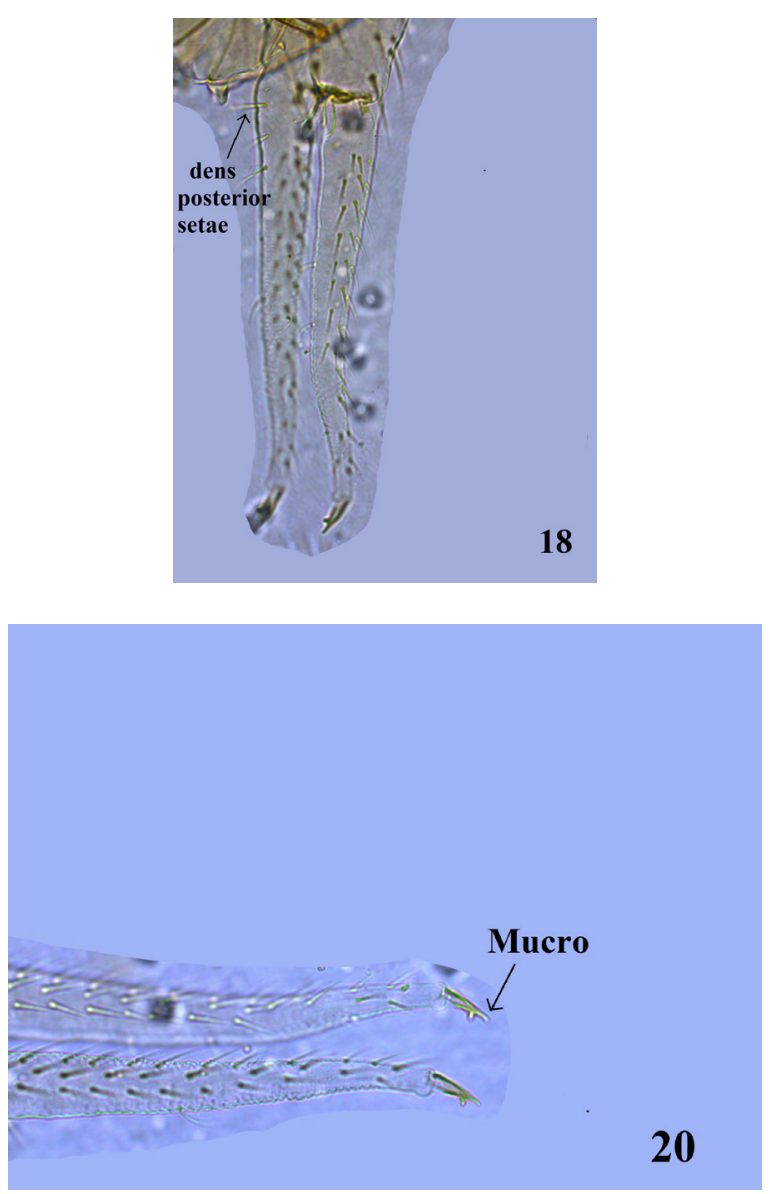

Figures 1-20. Folsomia arunachalensis n. sp. 1. Folsomia arunachalensis sp. nov. habitus (lateral view). 2. P.A.O. 3. Mouthparts. 4. Ant.I-II. 5. Microsensillum and sensillum. 6. Ant. III. 7. Ant. IV . 8. Th. II Chaetotaxy. 9. Th. III Chaetotaxy. 10. Abd.I Chaetotoxy. 11. Abd. II lateral chaetotoxy. 12. Abd. III Chaetotaxy. 13. Abd.IV-VI Chaetotoxy. 14. Ventral tube. 15. Tenaculum with setae. 16. Manubrial anterior setae. 17. Dens anterior setae. 18. Dens posterior setae. 19. Dens lateral setae. 20. Mucro. 


\section{Plate 3}
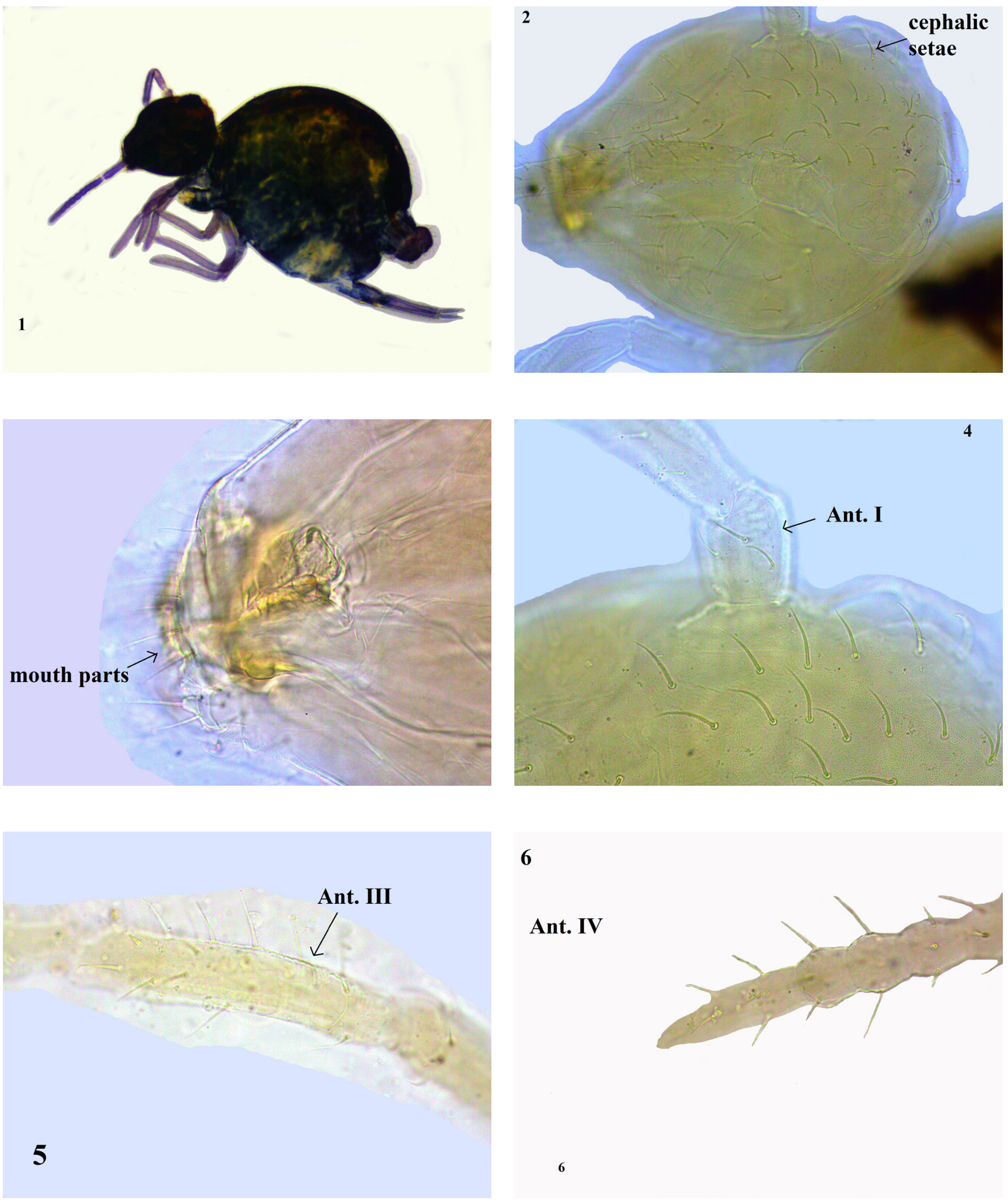

6

Ant. IV

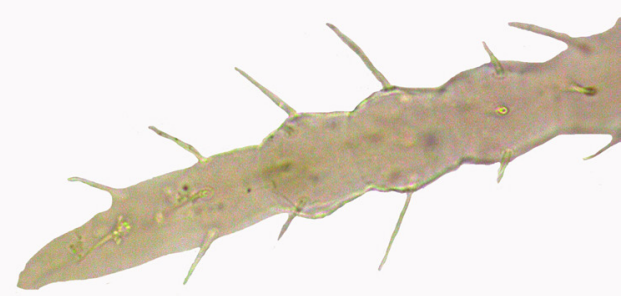

6 

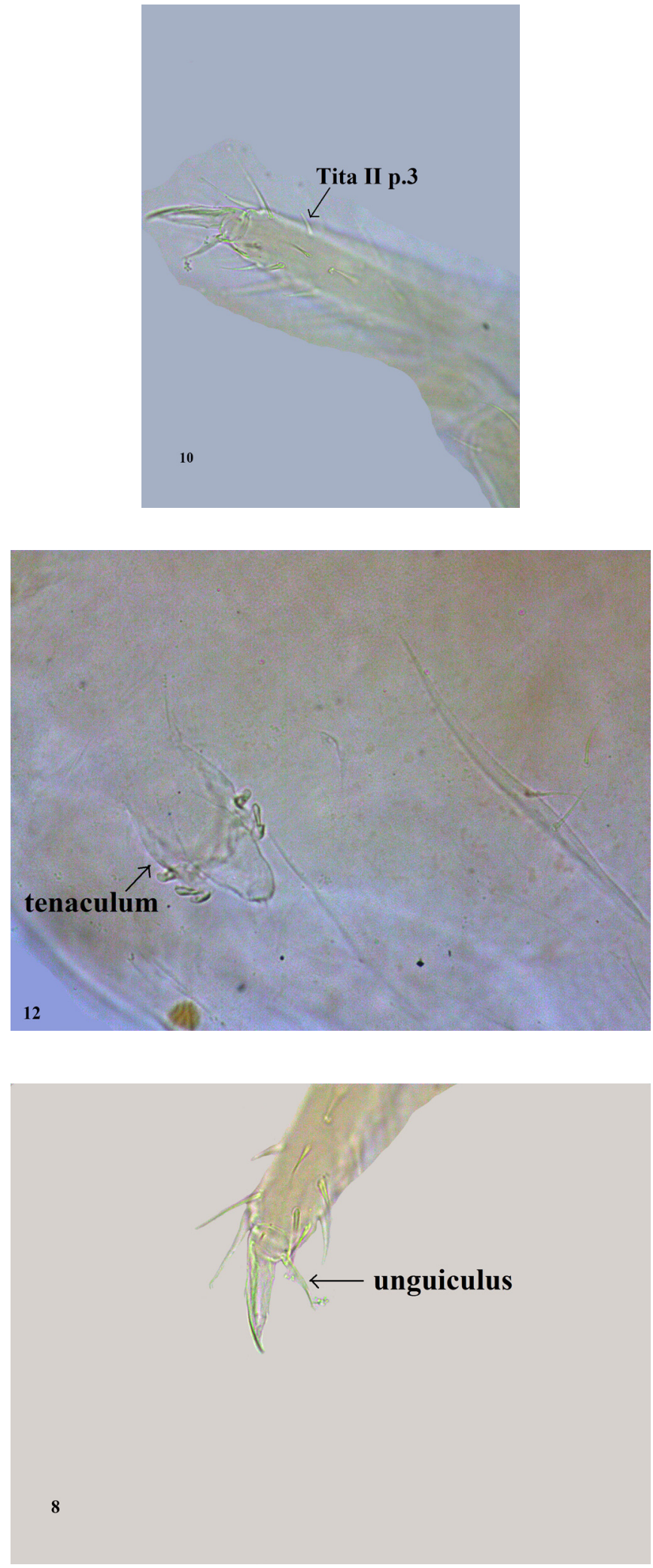
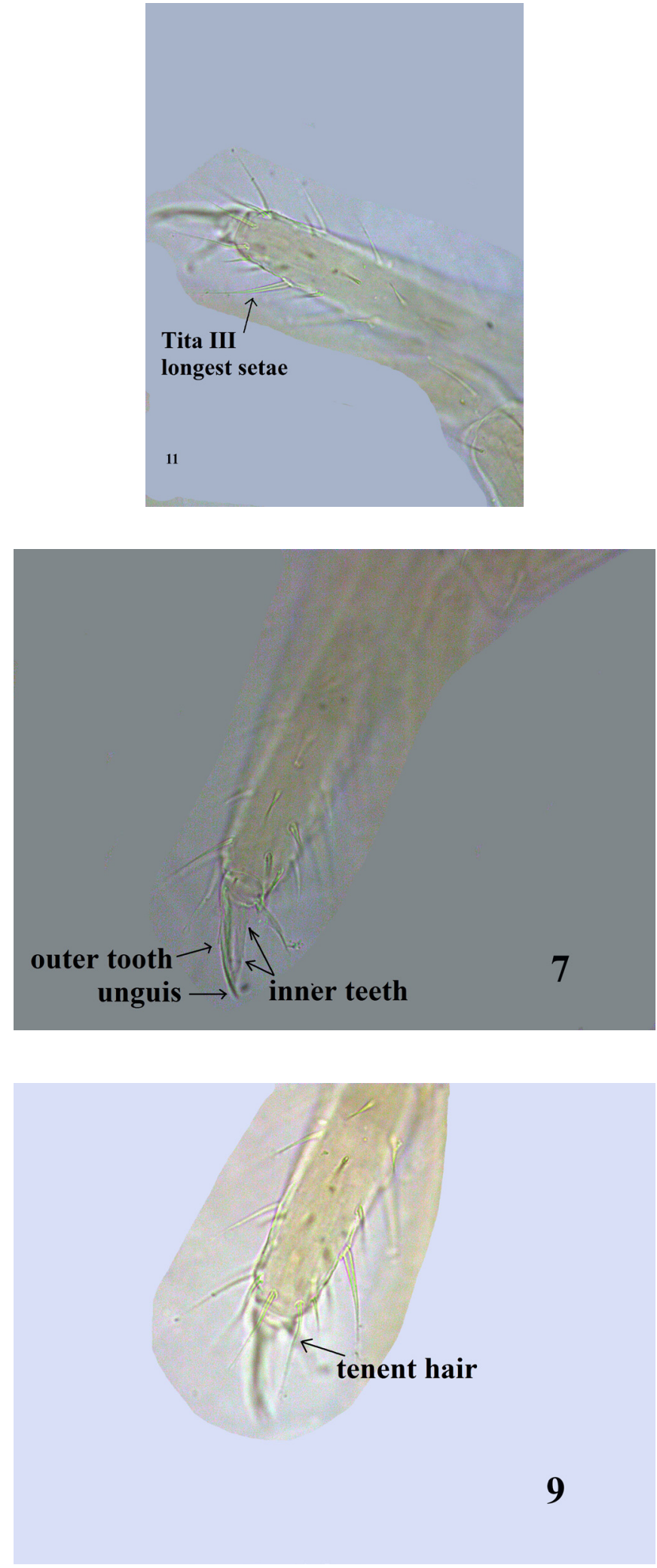

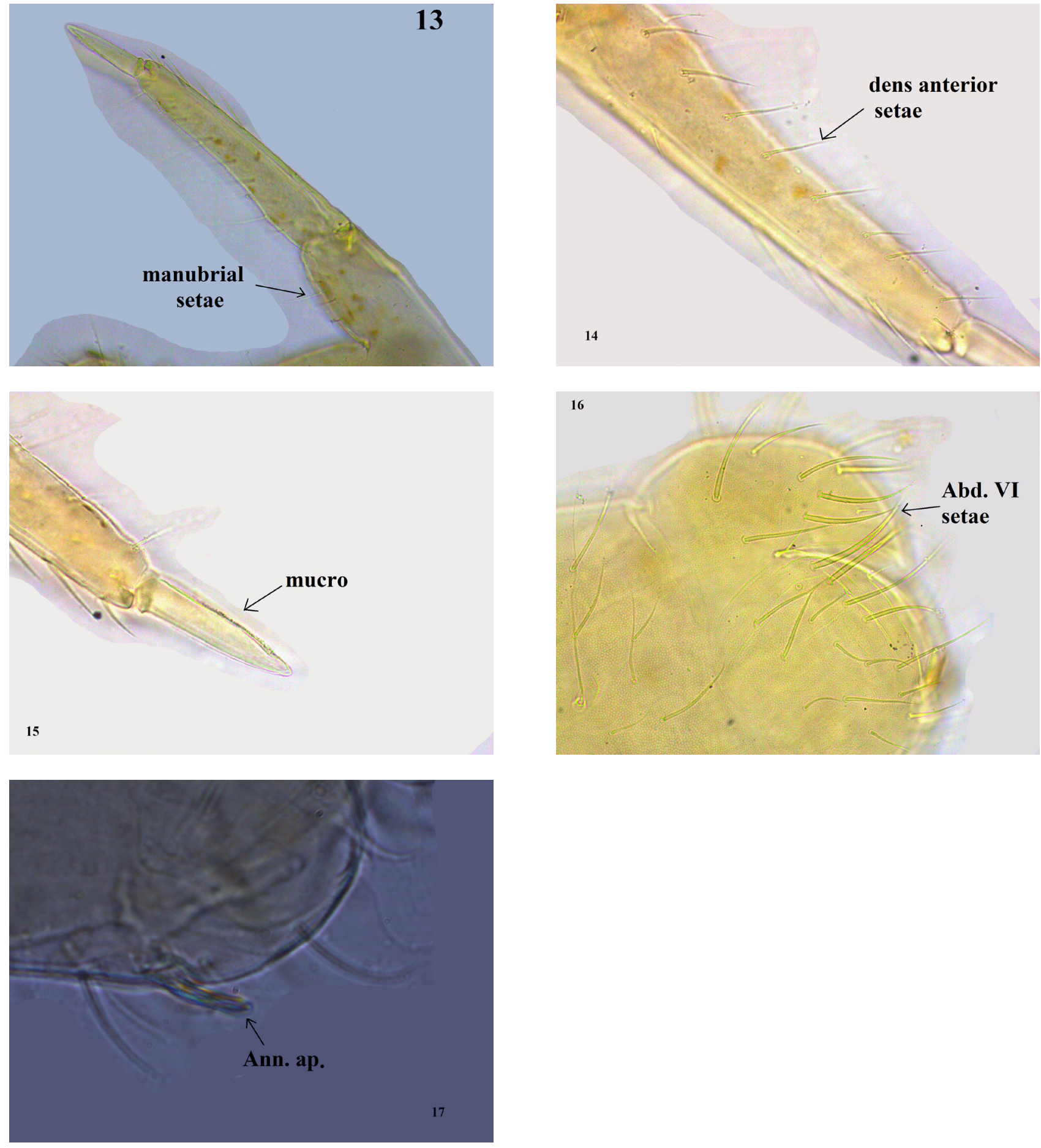

Figures 1-17. Bourletiella meghalayensis n. sp. 1. Bourletiella meghalayensis sp. nov. habitus (lateral view). 2. cephalic setae. 3. Mouthparts. 4. Ant.I. 5. Ant. III. 6. Ant. IV. 7. Unguis. 8. Unguiculus. 9. Tenent hair. 10. Tita II p.3. 11. Tita III longest setae. 12. Tenaculum. 13. Manubrial setae. 14. Anterior setae of dens. 15. Mucro. 16. Abd. VI. 17. Ann. ap.w 